\title{
GEOLOGY AND CHARACTERISTICS OF LOW SULPHIDATION EPITHERMAL VEIN IN SENEPO AREA, EAST JAVA
}

\section{GEOLOGI DAN KARAKTERISTIK ENDAPAN URAT EPITERMAL SULFIDA RENDAH DAERAH SENEPO, JAWA TIMUR}

\author{
ARIFUDIN IDRUS ${ }^{1}$ and ESTI HANDAYANI ${ }^{2}$ \\ ${ }^{1}$ Department of Geology Engineering, Gadjah Mada University \\ Bulaksumur, Yogyakarta 55281 \\ ${ }^{2}$ R\&D Centre for Mineral and Coal Technology \\ Jalan Jenderal Sudirman 623 Bandung 40211 \\ Ph. (+6222) 6030483, Fax. (+6222) 6003373 \\ e-mail: esti@tekmira.esdm.go.id
}

\begin{abstract}
Senepo area is one of several epithermal mineralization prospects in Southern Mountains of Java Island. This study is aimed to investigate the geological framework and hydrothermal alteration of the prospect as well as to characterize the low sulphidation (LS) epithermal vein including vein textures, ore mineral, ore chemistry and hydrothermal fluid that are responsible for the formation of the quartz vein. Detailed field mapping was completed to understand the geological framework and hydrothermal alteration zones. Petrographic, ore microscopic, XRD and AAS analyses were applied to characterize the quartz vein. The study area is occupied by pebbly sandstone, andesite breccia, andesite units and alluvial deposit. Ore mineralization is mainly hosted by andesite of Oligo-Miocene of Watupatok Formation. The host-rock has been suffered by overprinted hydrothermal alteration and weathering. The epithermal veins are found as $\mathrm{N}$-S-trending quartz veins with a thickness of 1-2 meters. These veins show massive texture, crustiform, cockade, druzy, comb, and disseminated sulphides, which is included in Crystalline Quartz Zonation (X). Optical microscopy and XRD analysis indicate that these veins contain several ore minerals such as chalcopyrite, sphalerite, galena, pyrite, hematite, covellite and malachite, associated with gangue mineral including quartz, felspar, chlorite and clay minerals. AAS analysis displays variable chemical composition of precious and base metals such as $\mathrm{Au}$ (17-37 ppb), Ag (8.1-32.6 ppm), $\mathrm{Cu}$ (122.1-81,450 ppm), Pb (35.4-883.6 ppm) and $\mathrm{Zn}(18.3-2,628 \mathrm{ppm})$. Gold and silver are relatively low compared to the base metals. Fluid inclusion micro thermometric analysis indicates that ore mineralization originated at temperatures of $187-263{ }^{\circ} \mathrm{C}$ and salinity of $0.18-0.53 \% \mathrm{wt}$. NaCl eq. This salinity corresponds with a minimum hydrostatic pressure of about 10-55.1 bars. Based on those characteristic data, mineralized quartz veins in the study area are classified into a base metal horizon of LS epithermal system.
\end{abstract}

Keywords: geology, alteration, characteristics, quartz vein, ore mineralization, Senepo

\begin{abstract}
ABSTRAK
Daerah Senepo merupakan salah satu daerah prospek di Pegunungan Selatan Jawa yang memiliki indikasi adanya mineralisasi tipe epitermal sulfidasi rendah. Penelitian dilakukan untuk mengetahui tatanan geologi, alterasi hidrotermal dan karaketristik endapan urat epitermal baik berupa tekstur urat, mineral bijih, kimia bijih dan fluida hidrotermal yang berperan dalam pembentukan endapan bijih tersebut. Metode penelitian yang dilakukan meliputi pemetaan geologi dan alterasi secara rinci, dan percontoh terpilih dianalisis menggunakan metode petrografi, mikroskopi bijih, XRD dan AAS. Stratigrafi daerah penelitian terdiri atas batupasir kerikilan, breksi andesitik, andesit dan endapan aluvial. Andesit, anggota Formasi Watupatok yang berumur Oligo-Miosen, merupakan batuan induk mineralisasi bijih serta telah mengalami alterasi dan pelapukan. Urat epitermal berupa urat-urat kuarsa berarah relatif utara-selatan dengan ketebalan 1-2 meter. Tekstur urat berupa urat masif, crustiform, cockade, druzy, comb, dan disseminated sulphide yang merupakan bagian zonasi urat Crystalline Quartz (X). Hasil analisis mikroskop optik dan XRD menunjukkan kehadiran mineral bijih berupa kalkopirit, sfalerit, galena, pirit,
\end{abstract}


hematit, kovelit dan malahit yang berasosiasi dengan mineral-mineral pengotor berupa kuarsa, felspar, klorit dan mineral lempung. Hasil analisis AAS menunjukkan kadar logam mulia dan logam dasar seperti $\mathrm{Au}$ (17-37 ppb), Ag (8,1-32,6 ppm), Cu (122,1-81.450 ppm), Pb (35,4-883,6 ppm) dan Zn (18,3-2.628 ppm). Kadar emas dan perak relatif rendah dibandingkan kadar logam dasar. Hasil analisis mikrotermometri inklusi fluida menunjukkan mineralisasi terbentuk pada temperatur $187-263{ }^{\circ} \mathrm{C}$ dan salinitas 0,18-0,53\%wt. $\mathrm{NaCl}$ eq. yang setara dengan tekanan hidrostatik minimum sebesar 10-55,1 bar. Berdasarkan data karakteristik di atas, maka urat kuarsa di daerah penelitan dikategorikan ke dalam horizon logam dasar sistem epitermal sulfida rendah.

Kata kunci: geologi, alterasi, karakteristik, urat kuarsa, mineralisasi bijih, Senepo

\section{INTRODUCTION}

Senepo area is situated in the eastern part of Southern Mountains of Java Island. It is included in Tertiary Java magmatic belt, which in some parts occurred hydrothermal ore mineralization. Hydrothermal ore mineralization in the eastern part of Southern Mountains is frequently discovered in Wonogiri, Pacitan, Ponorogo and Trenggalek Districts with various deposit types including low-sulfidation epithermal deposit, base metal vein, high sulfidation epithermal, skarn and Cu-Au porphyry. It was reported that in Slahung hydrothermal mineralization vein-type as a low-sulfidation epithermal system was discovered (Visaiphone, 2010). Widodo and Simanjutak (2002) concluded that Slahung is a part of the middle block of mineralization zone in the Southern Mountain Java. This area extends from Pacitan to Ponorogo and represents many outcrops of altered volcanic rocks. Common hydrothermal alteration such as silicification, propilytization, argilitization and kaolinization are recognized. Sulphide ore and quartz veins are found indicating the presence of magmatic activity that causes the hydrothermal process to form ore vein-type. In Nepo and Salak River at Slahung, base metal mineralization is identified in form of quartz vein with a thickness of 1.1-1.5 m, which contains ore minerals such as chalcopyrite and minor galena (Setijadji, 2009). Ngrayun is another prospect in Ponorogo district which is reported the presence of $\mathrm{N} 178^{\circ} \mathrm{E}$-trending quartz vein hosted by silicified rocks. This vein shows breccia texture containing several sulphides such as pyrite, chalcopyrite and galena (Hastuti, 2010).

The characteristics of the hydrothermal vein is an important key to determining zonation of the mineralization occurred in low- sulfidation epithermal system. According to Morrison, Guoyi and Jaireth (1990), vein texture of epithermal system is divided into three zones: $\mathrm{CH}$ zone (chalcedonic super zone), CC zone (crustiform-colloform super zone) and $X$ zone (crystalline super zone). These zones are directly compared with lowsulfidation epithermal system model of Buchanan (1981) to define the position within the system of the vein in the study area. For instance, two vein texture zones occurred in Cihonje Banyumas epithermal veins are identified namely CC zone, associated with the precious metal horizon $(\mathrm{Au}-\mathrm{Ag})$ and $\mathrm{X}$-zone, associated with base metal horizon (Cu-Pb-Zn) (Isyqi, Aziz and Idrus, 2016). In Soripesa Prospect, Sumbawa, quartz vein is found with various vein textures such as comb, crustiform, colloform, cockade and crystalline which are the key textures of low sulfidation epithermal deposit (Khant et al., 2012). This study is aimed to understand the geology and hydrothermal alteration as well as characteristics of the epithermal vein in Senepo Area, Slahung district, Ponorogo regency by identifying vein textures, ore minerals, ore chemistry and mineralizing fluid in order to determine the mineralization zone of the LS epithermal system.

\section{REGIONAL GEOLOGY}

Ponorogo, especially Senepo area is located in the eastern part of Southern Mountains zone (Figure 1A; Van Bemmelen, 1949). Generally, it is expressed by undulating morphology and composed of Early Miocene volcanic rocks, a member of Watupatok Formation (Figure 1B) that contain andesitic lava with interbedded sandstone-claystone and chert (Samodra, Gafoer and Tjokrosapoetro, 1992). Geological structures of the eastern part of East Java Southern Mountains consist of fold and faults. 
According to direction, the faults can be divided into four groups, including northeastsouthwest, west-east, northwest-southeast, and north-south trending faults (Sampurno and Samodra, 1997).

\section{METHODS}

Fieldwork was focused on mapping out deposit geology and hydrothermal alteration. Some representative samples of quartz vein were collected to be analysed by optical microscopy (petrography and ore microscopy), X-ray diffraction (XRD), atomic absorption spectrometry (AAS) and fluid inclusion micro-thermometry. Ore microscopy analysis was conducted to determine the ore mineralogy of the quartz vein. Metalliferous minerals are determined by polished section ore microscopic analysis, whereas nonmetalliferous mineral identification was performed by thin section petrographic analysis. Mineral phases particularly clay minerals occurred in quartz vein were identified by XRD analysis. Petrography, ore microscopy and XRD analyses that were conducted at Department of Geological Engineering, Gadjah Mada University. Ore chemistry particularly for $\mathrm{Au}, \mathrm{Ag}, \mathrm{Cu}, \mathrm{Pb}$ and $\mathrm{Zn}$ was determined by AAS method at PSG Bandung. Fluid inclusion micro-thermometric analysis using Linkam THMS600 freezing and heating stage provides data of the temperature of homogenization (Th), the temperature of melting $(\mathrm{Tm})$ and salinity, thus the pressure and the paleodepth of quartz vein formation enables to be interpreted. Fluid inclusion micro-thermometry was analysed at the Research Center for Geotechnology, Indonesian Institute of Sciences - Bandung.

\section{RESULTS AND DISCUSSION}

\section{Local Geology}

The study area is occupied by four stratigraphy units (from older to younger) including pebbly sandstone, andesitic breccia and andesite as well as the alluvial deposit (Figure 2). Ore mineralization is mainly hosted by andesite, a member of Oligo-Miocene Watupatok Formation. This unit is characterized by porphyroaphanitic texture containing plagioclase phenocrysts set in microlith groundmass. Both phenocryst and groundmass were replaced partially by secondary minerals such as clay minerals, sericite and chlorite. North-south and southwest-northeast trending strike-slip faults may be responsible for the ore mineralization in the study area.

\section{Hydrothermal Alteration}

Andesite has been suffered by various overprinted hydrothermal alteration. Three hydrothermal alteration zones are delineated consisting of silicic, propylitic argillic types (Figure 3). Silicic alteration occurred around quartz veins and characterized by the occurrence of chalcedony or secondary quartz. The temperature of the formation is about $140^{\circ} \mathrm{C}$ (for chalcedony) or $200-330^{\circ} \mathrm{C}$ (for quartz) (Hedenquist et al., 1996). Propylitic alteration occurred at the outer zone. This alteration type is characterized by chlorite, quartz, albite and pyrite which was originated at temperature of about 200$310^{\circ} \mathrm{C}$ (Hedenquist et al., 1996). Argillic alteration is typified by clay minerals replacing plagioclase. XRD analysis indicates that clay minerals are composed of montmorillonite, kaolinite and illite, which formed at the temperature of about 100$210^{\circ} \mathrm{C}$ (Hedenquist et al., 1996).

\section{Vein Textures}

Several LS epithermal quartz veins were found in Senepo area. Salak vein is the main vein which has relatively south-north to a southwest-northeast direction and 1-2 m thick (Figure 4). The quartz vein shows a typical open space filling texture including massive, crustiform, cockade, comb, druzy and disseminated sulphides (Figure 5). The massive vein is composed of crystalline quartz associated with sulphide minerals (chalcopyrite, covellite, sphalerite, galena, and pyrite) which exhibit disseminated ore texture. Crustiform texture showing repetitive bands is a common texture as a diagnostic feature of LS epithermal veins (Buchanan, 1981). The presence of crustiform texture reflects fluctuating concentration of elements in solution and fluctuating fluid conditions during minerals precipitation. Some concentric crustiform bands of quartz or sulphide minerals are found surrounding isolated wallrock fragment. It formed cockade texture and well developed at the outer part of the vein that is contacted with the wallrock. Druzy and comb textures are also found in 
some parts of orebody as the result of open space filling. Comb texture is formed by slow cooling of the system and uniform growth from multiple nuclei along a vein wall. According to vein texture zonation by
Morrison, Guoyi and Jaireth (1990), the characteristics of vein textures in the study area is categorized into Crystalline Quartz (X) zone which is composed of crystalline quartz + sulphide minerals \pm crustiform texture.

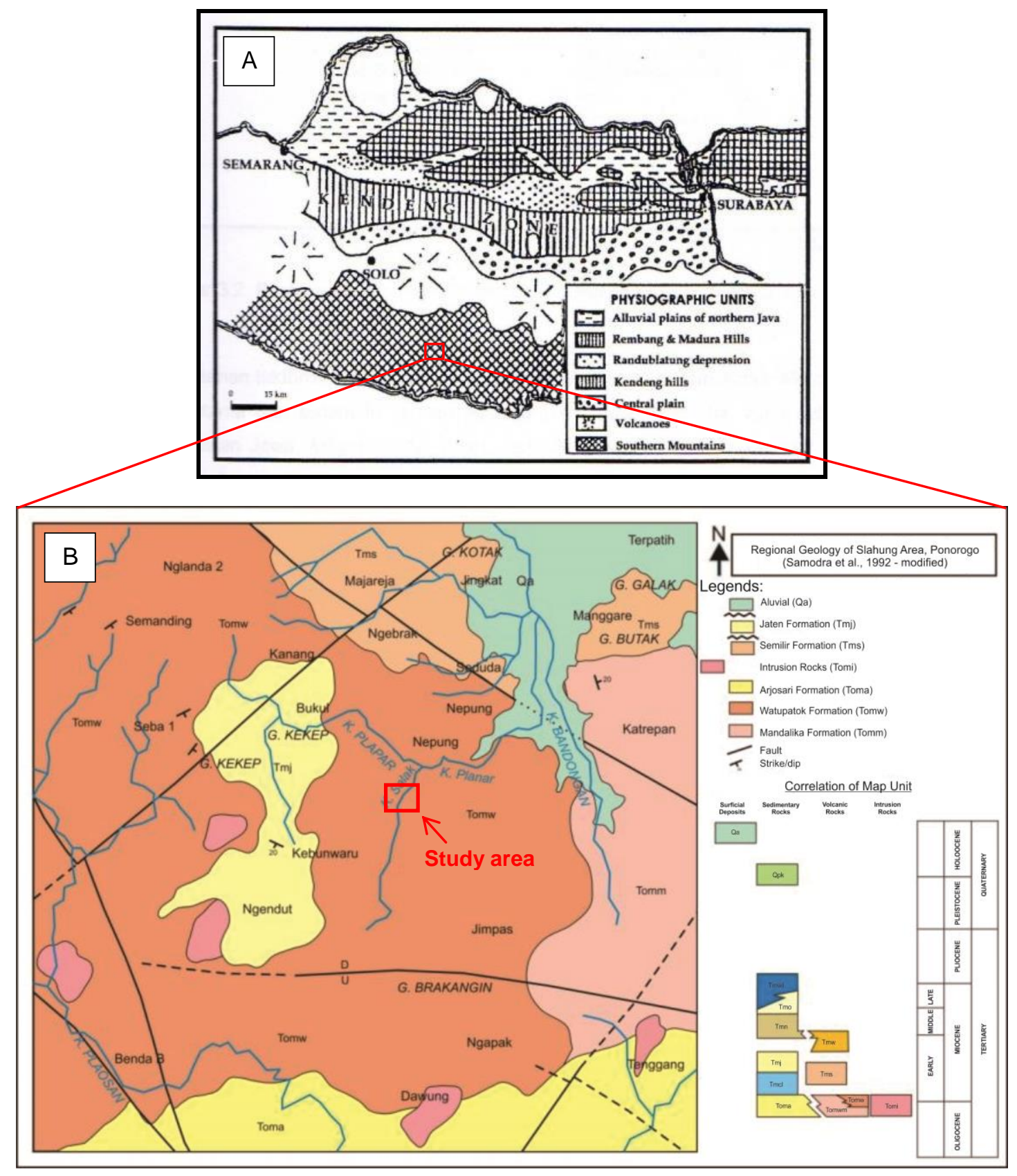

Figure 1. [A] Physiography of study area located at Southern Mountains zone of East Java (van Bemmelen, 1949) and [B] Regional geological map of research area (Samodra, Gafoer and Tjokrosapoetro, 1992). 

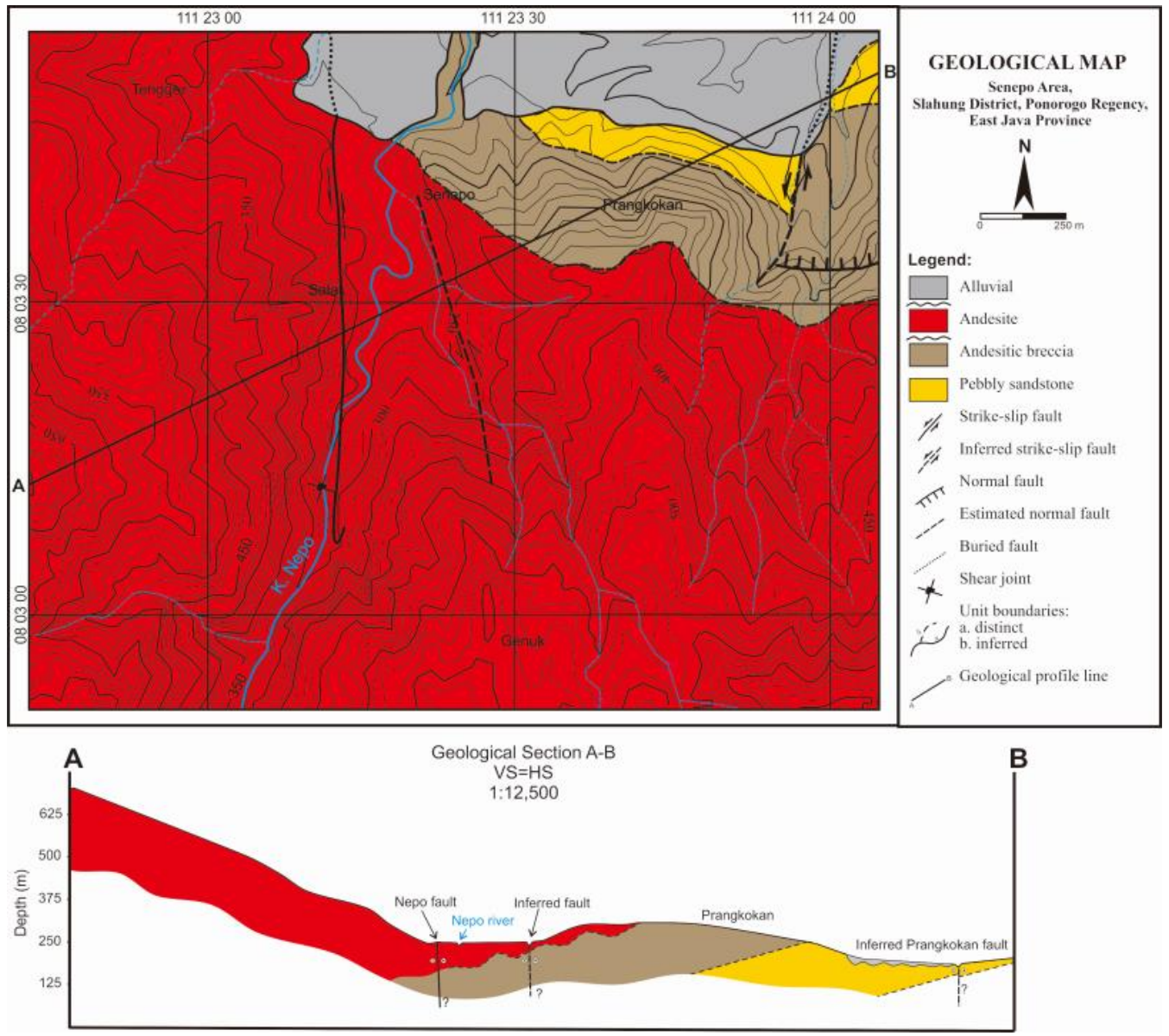

Figure 2. Geological map and section (A-B) of Senepo area, Ponorogo Regency, East Java Province.

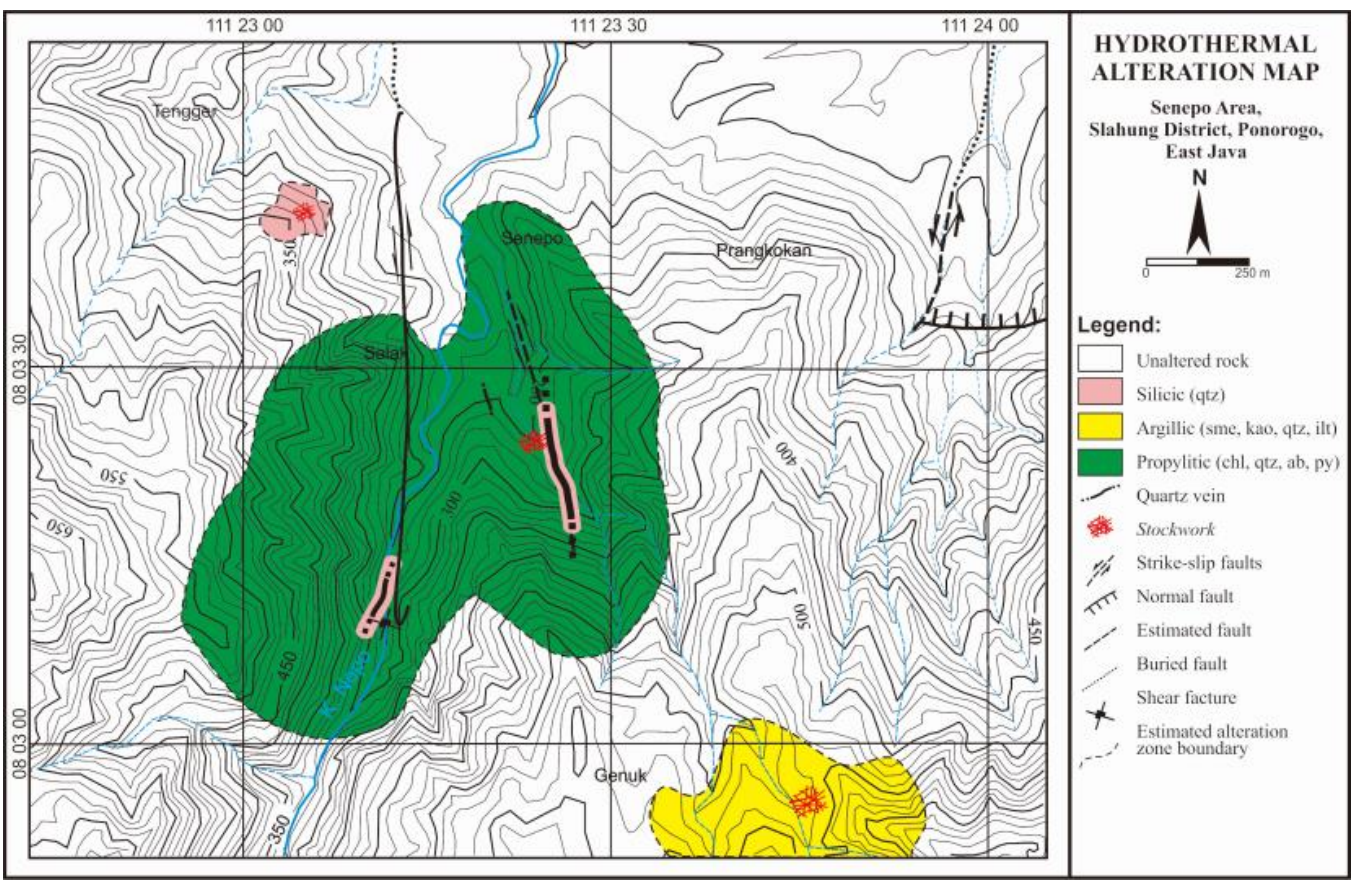

Figure 3. Hydrothermal alteration map of Senepo area, Ponorogo Regency, East Java Province. 


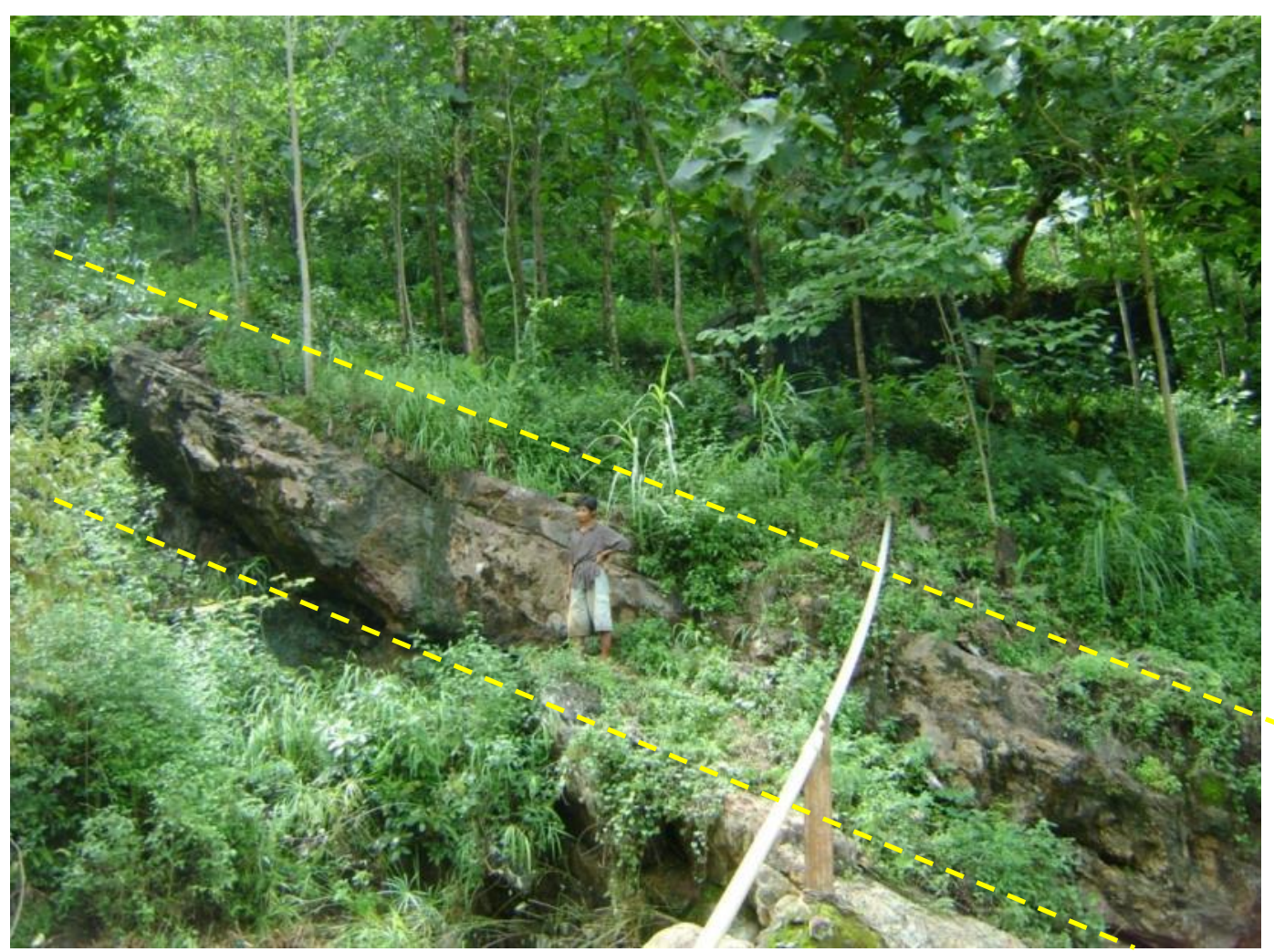

Figure 4. Salak quartz vein around 1-2 m of thickness in Senepo area.
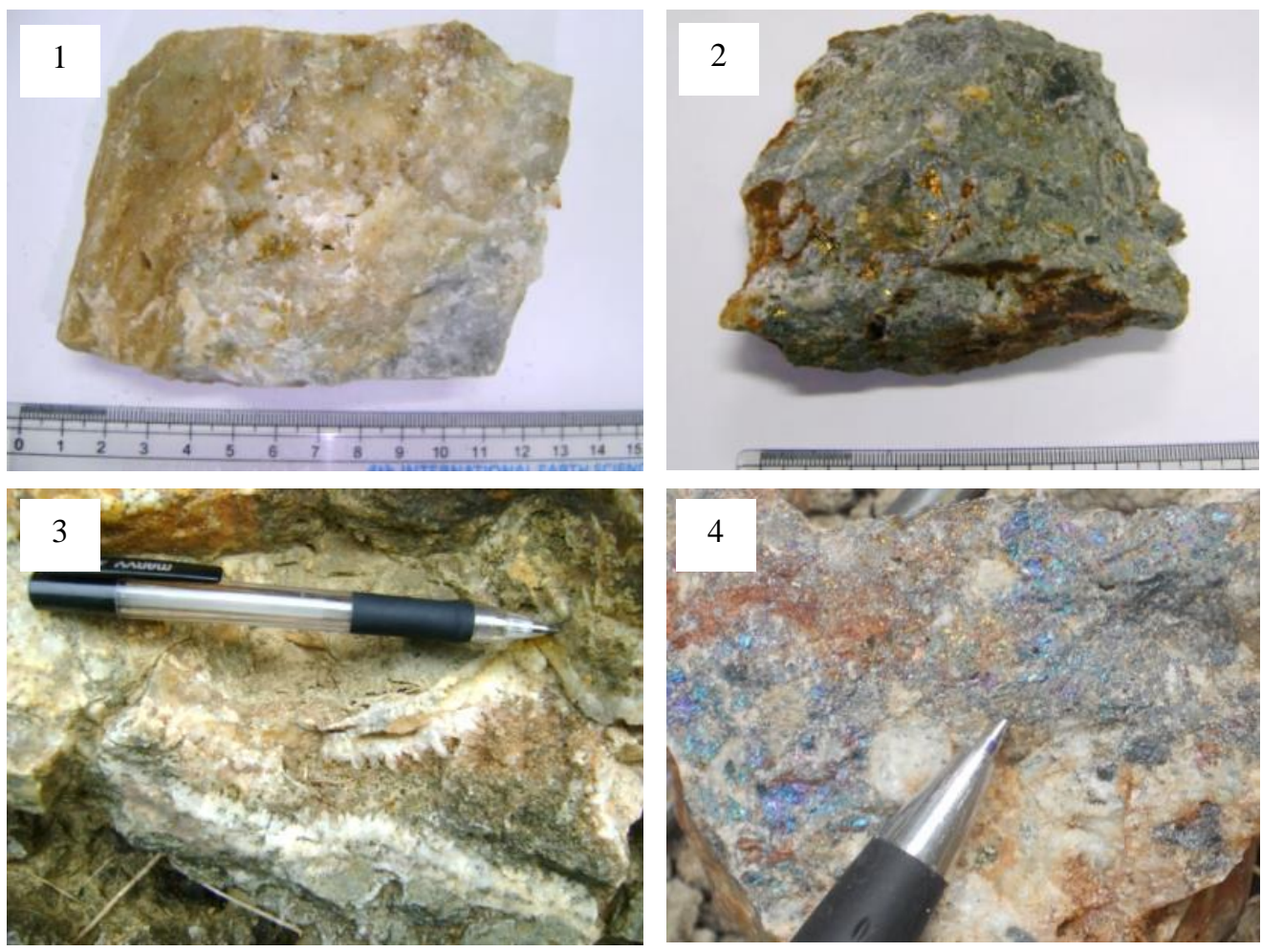

Figure 5. Samples of quartz veins showing various epithermal textures: (1) massive, (2) cockade, (3) crustiform, comb, and druzy and (4) disseminated sulphide. 


\section{Ore and Gangue Mineralogy}

The LS epithermal quartz vein in Senepo area contains both ore and gangue minerals identified by ore microscopy, petrography and XRD analyses. Figure 5 shows various textures of quartz veins associated with sulphides. Chalcopyrite $\left(\mathrm{CuFeS}_{2}\right)$, galena $(\mathrm{PbS})$, sphalerite $(\mathrm{ZnS})$ and pyrite $\left(\mathrm{FeS}_{2}\right)$ are obviously observed under ore microscopy. Covellite (CuS), malachite $\left(\mathrm{Cu}_{2}(\mathrm{OH})_{2} \mathrm{CO}_{3}\right)$ and hematite $\left(\mathrm{Fe}_{2} \mathrm{O}_{3}\right)$ are also identified as secondary or supergene minerals. $\mathrm{Cu}$ bearing minerals are represented by chalcopyrite, covellite and malachite. Chalcopyrite is primary Cu-bearing sulphide which is commonly disseminated within quartz vein. It is found as single grain or bound with other minerals and as inclusion in sphalerite. Both covellite and malachite are identified as secondary minerals replacing chalcopyrite. It is interpreted that covellite formed in supergene enriched zone while malachite together with hematite replaced chalcopyrite in gossan zone (Koski, 2012). The other primary ore minerals are sphalerite and galena. Under the microscope, sphalerite has a gray color and contains chalcopyrite inclusions called chalcopyrite disease. This condition indicates that the sphalerite-rich in Fe content (Kojima, 1992) and the mineral deposit was formed in relatively high temperature $\left(\sim 300^{\circ} \mathrm{C}\right)$ (Idrus et al., 2013). Galena, under the microscope, has a typical presence of triangular pits. Triangular pits are dark triangles in galena as a result of three different directions of galena cleavage. Figure 6 shows the photomicrograph of epithermal vein from study area; (1) chalcopyrite was replaced by hematite partially and contains cube pyrite inclusion, (2) chalcopyrite as inclusion in the sphalerite (chalcopyrite disease) and covellite attached sphalerite as the result of chalcopyrite replacement.

Gangue minerals were observed by petrography and XRD analysis. Under the microscope, quartz vein predominantly consists of quartz with minor feldspar, chlorite, clay minerals and opaque minerals. The presence of chlorite and clay minerals as secondary minerals is interpreted as a result of hydrothermal alteration at isolated wallrock fragment within the epithermal vein. Clay minerals were identified as sericite and illite by XRD analysis (Figure 7). Figure 8 show the photomicrograph of quartz vein that consists of abundant crystalline quartz, a small amount of opaque minerals and several chlorites.

\section{Ore and Sphalerite Chemistry}

The bulk chemical composition of quartz veins is presented in Table 1. Ore chemical analysis of quartz vein by means of AAS shows the variable content of precious and base metals as follows: 17-37 ppb Au, 8.132.6 ppm Ag, 122.1-81,450 ppm Cu, 35.4883.6 ppm $\mathrm{Pb}$ and 18.3-2,628 ppm Zn, respectively. Base metal of $\mathrm{Cu}-\mathrm{Pb}-\mathrm{Zn}$ content corresponds well with the presence of base metal-bearing sulphides such as chalcopyrite, galena and sphalerite. Precious metal of $\mathrm{Au}$ and $\mathrm{Ag}$ contents are typically low compared to those of base metals.
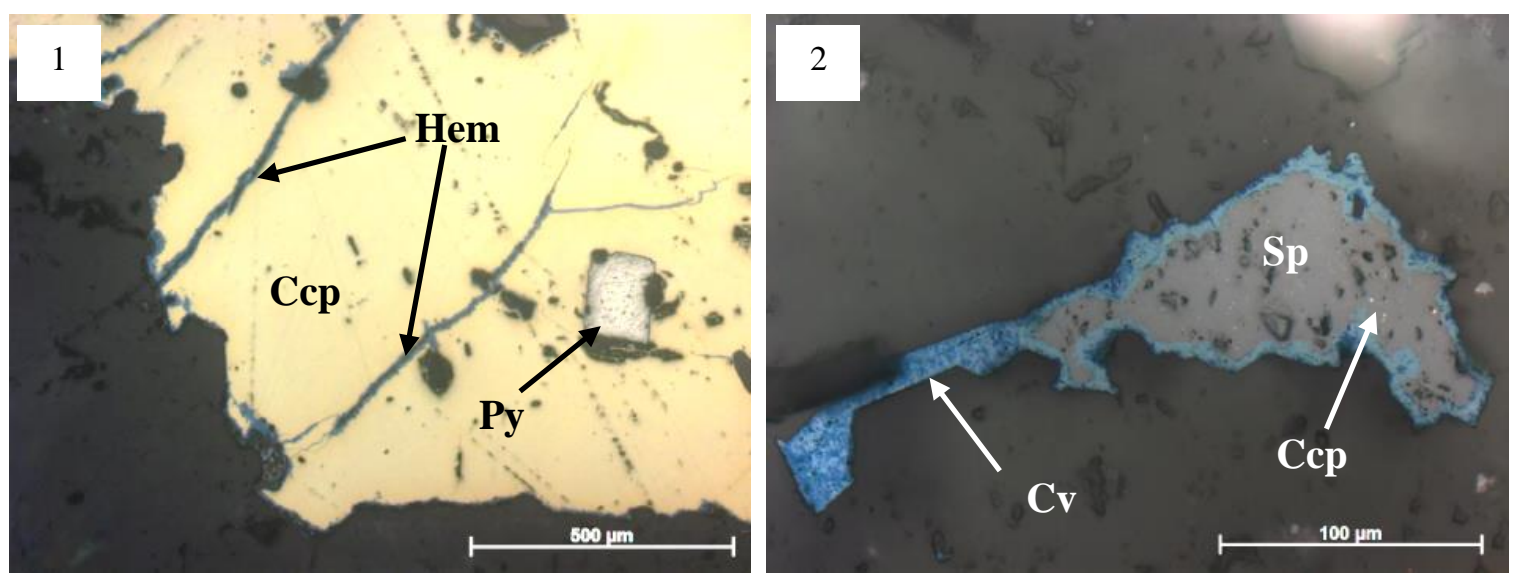

Figure 6. Ore microscopic images of quartz vein containing ore minerals: (1) pyrite [Py], chalcopyrite [Ccp] and hematite [Hem]; (2) covellite [Cv], sphalerite [Sp], and chalcopyrite [Ccp]. 


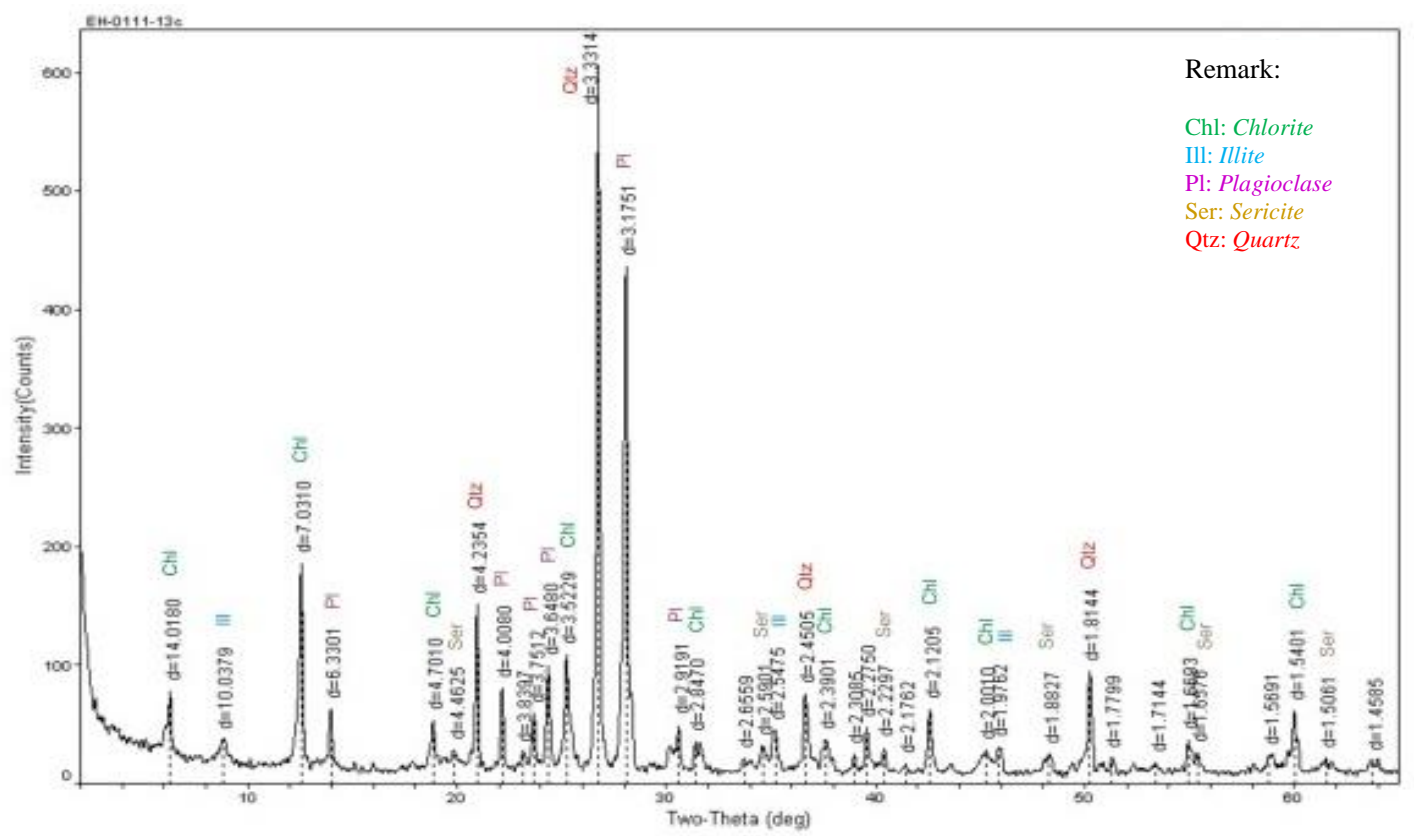

Figure 7. XRD diagram of quartz vein containing quartz, plagioclase, chlorite and clay minerals (illite and sericite).

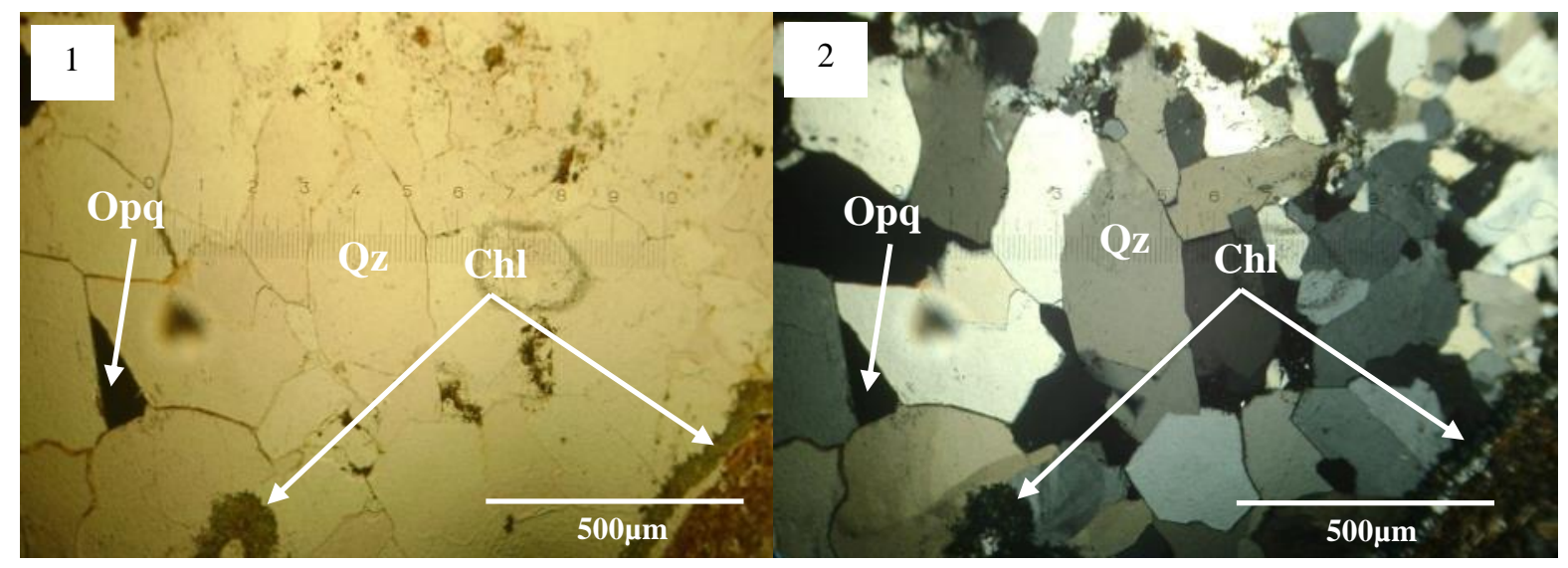

Figure 8. Polarized-light microscopic images of epithermal quartz vein containing quartz [Qtz], opaque minerals [Opq] and chlorite [Chl]; (1) parallel nicol and (2) cross nicol.

Table 1. Ore chemistry of Salak quartz veins (AAS)

\begin{tabular}{cccccc}
\hline Sample & \multicolumn{5}{c}{ Precious \& base metals (ppm) } \\
\cline { 2 - 6 } Code & $\mathrm{Cu}$ & $\mathrm{Pb}$ & $\mathrm{Zn}$ & $\mathrm{Au}$ & $\mathrm{Ag}$ \\
\hline 01 & 1,689 & 603.2 & 1,182 & 0.019 & 13 \\
02 & 4,352 & 35.4 & 223.2 & 0.017 & 12.2 \\
03 & 16,853 & 438.2 & 990 & 0.019 & 16.8 \\
04 & 81,450 & 883.6 & 2,628 & 0.02 & 32.6 \\
05 & 122.1 & 82.5 & 18.3 & 0.037 & 8.1 \\
\hline
\end{tabular}




\section{Fluid Inclusion Micro-thermometry}

Fluid inclusion consists of primary and secondary types. They are clustered and randomly distributed. Both monophase $(\mathrm{L})$ and biphase $(\mathrm{L}+\mathrm{V})$ inclusion phases are water dominated. Primary fluid inclusions of $2-4 \mu \mathrm{m}$ size are occupied along primary crystals growth zone and isolated. Secondary fluid inclusions of $0.1-2 \mu \mathrm{m}$ size formed along micro-fracture zone and sometimes showing a necking-down texture and decripitated. Figure 9 shows the presence of various types of fluid inclusions within quartz crystals.

Micro-thermometric analysis of measurable fluid inclusions indicates the temperature of homogenization (Th) varies between 187 and $263^{\circ} \mathrm{C}$ (modus of Th) with the temperature of melting $(\mathrm{Tm})$ is around -0.1 to $-0.3^{\circ} \mathrm{C}$. Calculated fluid salinity ranges from $0.18-0.53$ wt.\% $\mathrm{NaCl}$ eq., which is relatively very low, as an indication of predominant meteoric water origin. Based on the thermal profile by Haas (1971), it can be assumed that ore mineralization occurred at a minimum hydrostatic pressure of about 10-55.1 bars, which is equivalent to $100-550 \mathrm{~m}$ depth. The relationship between homogenization temperature (Th) and salinity range is used to determine the deposit type of the veins plotted on Th-salinity diagram by Wilkinson (2001). As a result, the mineralized Senepo quartz vein is categorized into LS epithermal deposit type (Figure 10).

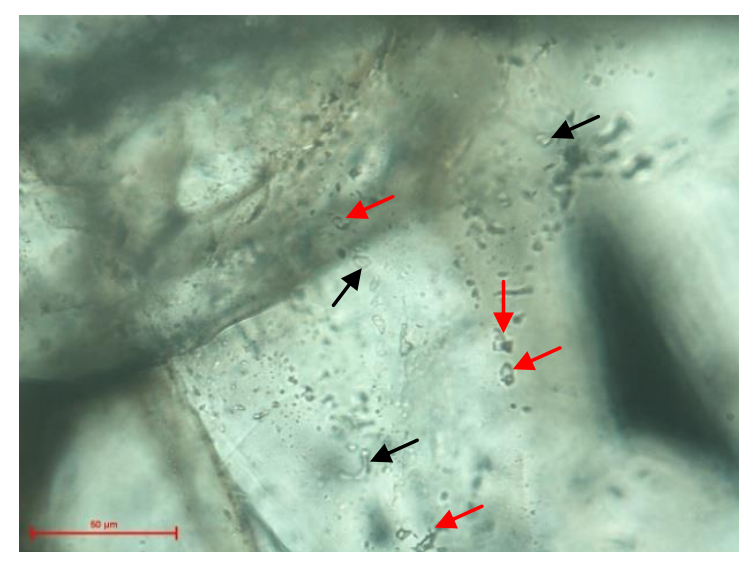

Figure 9. Primary fluid inclusions: biphase (red arrows), liquid rich, formed at crystal growth zones; and secondary fluid inclusions: very fine size, monophase (black arrows), and liquid rich, present as clusters as well as at crystal growth zones or along micro-fracture zones inside crystal quartz.

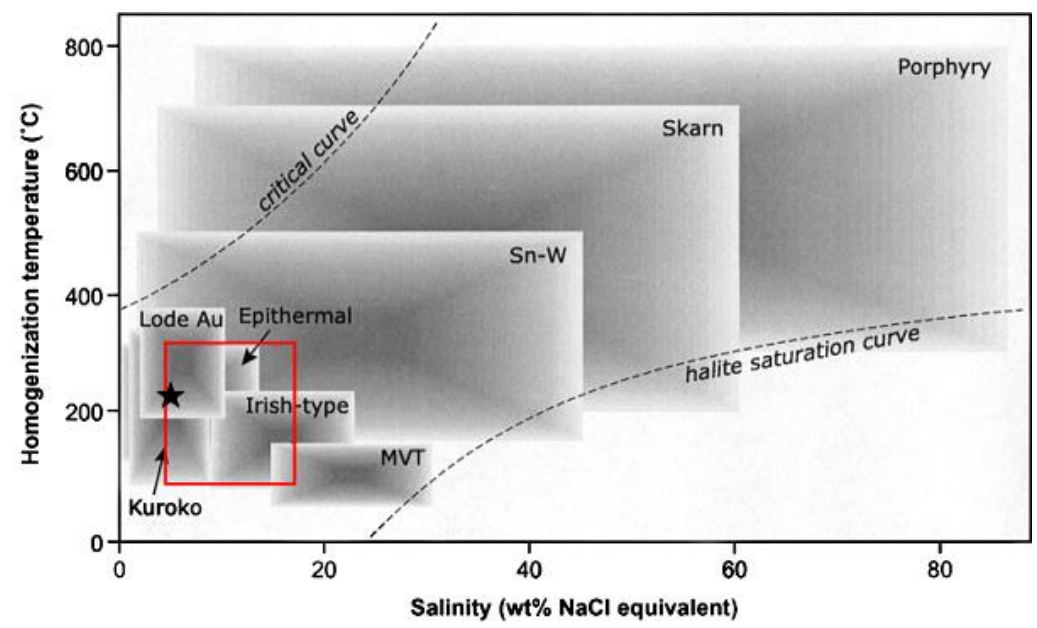

Figure 10. Temperature-salinity diagram (cf. Wilkinson, 2001) plot showing fluid inclusion microthermometric data ( $\star$ ) falls into LS epithermal system. 


\section{Ore Mineralization Zonation}

Based on the deposit characteristics of quartz vein in study research area corresponds to base metal horizon of LS epithermal system (cf. Buchanan, 1981; Figure 11). Base metal horizon is characterized by the presence of $\mathrm{Cu}-\mathrm{Pb}-\mathrm{Zn}$ bearing sulphides such as chalcopyrite, galena and sphalerite as well as gangue minerals (quartz, pyrite and chlorite) associated with Crystalline Quartz $(X)$ zone. This horizon occurred at an averaging moderate temperature of $\sim 225^{\circ} \mathrm{C}$, situated below boiling level. The quartz vein is interpreted to be originated at $300-425 \mathrm{~m}$ beneath paleodepth. The enrichment of base metal elements is compatible with the reducing of precious metal (Au-Ag) content.

\section{CONCLUSIONS}

Senepo quartz veins show massive, cockade, druzy, comb, crustiform and disseminated sulphide textures. Those open space filling textures are typically present in Crystalline Quartz Zonation (X). Ore microscopy and $X R D$ analyses indicate that the quartz veins contain ore mineral assemblages of chalcopyrite, sphalerite, galena, pyrite, hematite, covellite and malachite, associated with gangue mineral such as quartz, feldspar, chlorite and clay minerals (illite and sericite). AAS assay analysis displays variable precious and base metal contents including 17-37 ppb Au, 8.1-32.6 ppm Ag, 122.181,450 ppm Cu, 35.4-883.6 ppm $\mathrm{Pb}$ and 18.3-2,628 ppm Zn. Precious metals of $\mathrm{Au}$ and $\mathrm{Ag}$ are typically very low in comparison with those of base metal elements. Microthermometric fluid inclusion analysis portrays that ore mineralization occurred at the temperature of $187-263^{\circ} \mathrm{C}$, the low salinity of $0.18-0.53$ wt. $\% \mathrm{NaCl}$ eq., the minimum hydrostatic pressure of about 10-55.1 bars, which is equivalent with $100-550 \mathrm{~m}$ below paleodepth. Based on those characteristic data, the mineralized quartz veins in the study area is classified as a base metal horizon of LS epithermal system.

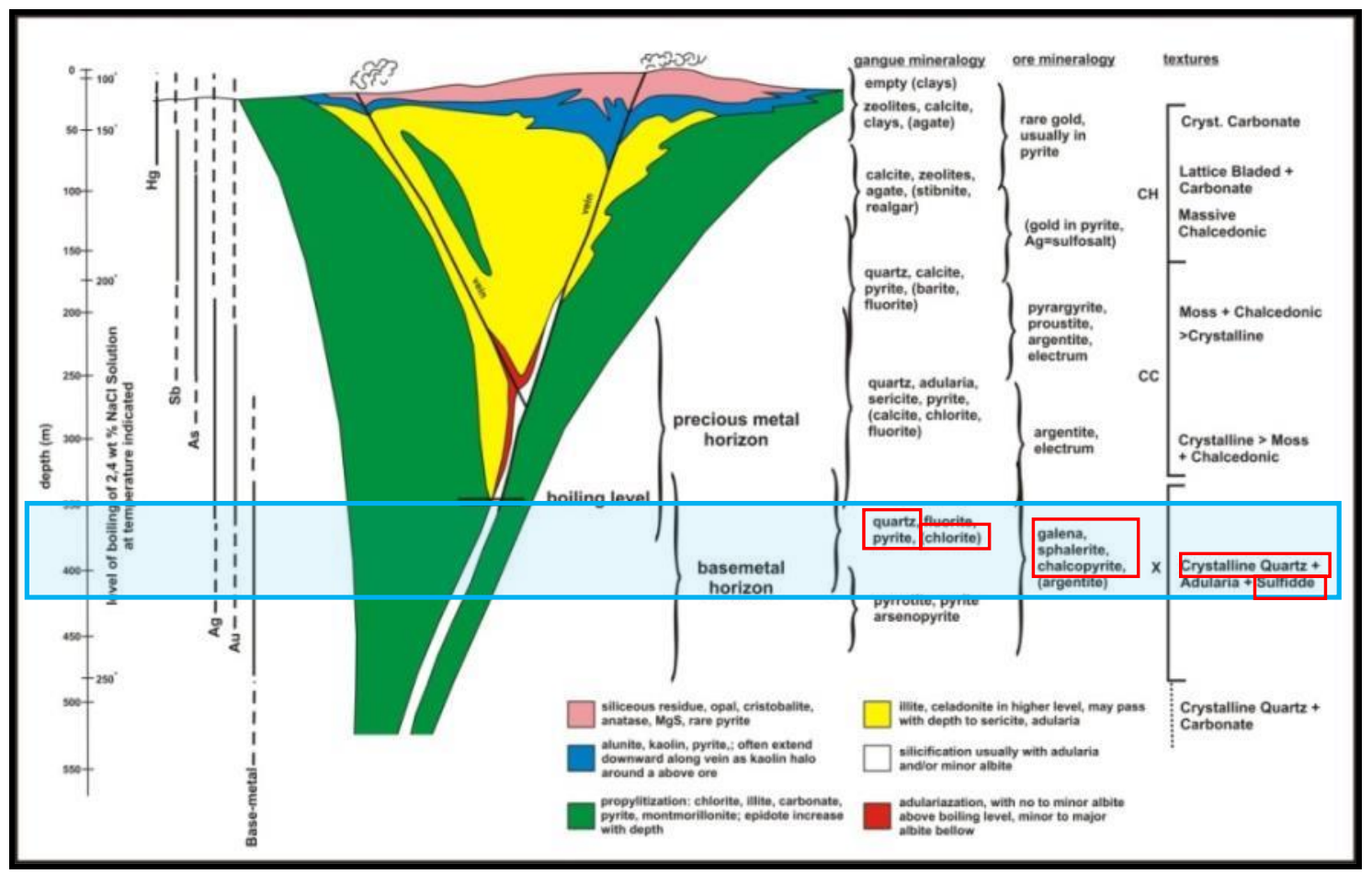

Figure 11. Senepo quartz vein categorized into base metal horizon of LS epithermal zonation (Buchanan, 1981). 


\section{ACKNOWLEDGEMENT}

The authors would like to appreciate Department of Geological Engineering, Gadjah Mada University for granting the financial research. Thanks also to Senepo society for giving permission to collect field data in the study area.

\section{REFERENCES}

Buchanan, L. J. (1981) "Precious metal deposits associated with volcanic environments in the southwest," Arizona Geol. Soc. Digest, 14, pp. 237-261.

Haas, J. L. (1971) "The effect of salinity on the maximum thermal gradient of a hydrothermal system at hydrostatic pressure," Economic Geology, 66(6), pp. 940-946. 10.2113/gsecongeo.66.6.940.

Hastuti, E. W. D. (2010) "Karakteristik struktur geologi di daerah mineralisasi logam dasar: studi kasus ngrayun dan sekitarnya, Ponorogo, Jawa Timur," Jurnal Rekayasa Sriwijaya, 19(2), pp. 45-54.

Hedenquist, J. W., Izawa, E., Arribas, A. and White, N. C. (1996) Epithermal gold deposits. styles, characteristics and exploration. No. 1. Resources Geology Special Publication.

Idrus, A., Hakim, F., Kolb, J., Appel, P. and Aziz, M. (2013) "Ore and alteration mineralogy of Paningkaban-Cihonje gold prospect, Gumelar Sub-District, Banyumas Regency, Central Java: A new discovery of carbonate base metal gold epithermal deposit," in Proceedings of International Conference on Geological Engineering. Yogyakarta: Gadjah Mada University, pp. 80-86. Available at: https://repository.ugm.ac.id/96983.

Isyqi, I., Aziz, M. and Idrus, A. (2016) "Karakteristik tekstur dan zonasi endapan urat epitermal daerah Cihonje, Kecamatan Gumelar, Kabupaten Banyumas, Jawa Tengah," Jurnal RISET Geologi dan Pertambangan, 26(1), p. $23 . \quad$ doi: 10.14203/risetgeotam2016.v26.258.

Khant, W., Warmada, I., Idrus, A. and Watanabe, K. (2012) "Alteration mineralogy and quartz texture of polymetallic epithermal quartz veins at Soripesa prospect area, Sumbawa Island, Indonesia," in Proceedings of the 2nd Asia Africa Mineral Resources Conference 2012. Bandung. Available https://www.researchgate.net/publication/2 59990678_Alteration_Mineralogy_and_Qu artz_Textures_of_Polymetallic_Epithermal _Quartz_Veins_at_Soripesa_Prospect_Ar ea_Sumbawa_Island_Indonesia.

Kojima, S. (1992) "The nature of chalcopyrite inclusions in sphalerite; exsolution, coprecipitation, or 'disease'?; discussion," Economic Geology, 87(4), pp. 1191-1192. doi: 10.2113/gsecongeo.87.4.1191.

Koski, R. A. (2012) Supergene ore and gangue characteristics. Virginia. Available at: https://pubs.usgs.gov/sir/2010/5070/c/Cha pter12SIR10-5070-C-3.pdf.

Morrison, G., Guoyi, D. and Jaireth, S. (1990) Textural zoning in epithermal quartz veins. Townsville: Klondike Exploration Services.

Samodra, H., Gafoer, S. and Tjokrosapoetro, S. (1992) Peta geologi lembar Pacitan, Jawa Timur. Bandung. Available at: https://www.dropbox.com/s/46y0hc9ijxssz 78/34-1507-4-Pacitan.jpg?dl=0.

Sampurno and Samodra, H. (1997) Peta geologi lembar Ponorogo, Jawa Timur. Bandung.

Setijadji, L. D. (2009) "Gold-related deposits in the southern mountains of East Java, Indonesia," in International Conference Earth Science and Technology. Yogyakarta.

van Bemmelen, R. W. (1949) The geology of Indonesia vol. II: Economic geology. The Hague.

Visaiphone, S. (2010) Geology and characteristics of ore mineral deposits at Slahung Area, Ponorogo Regency, East Java, Indonesia. Gadjah Mada University. Available at: http://etd.repository.ugm.ac.id/index.php? mod=penelitian_detail\&sub=PenelitianDet ail\&act=view\&typ=html\&buku_id=47207.

Widodo, W. and Simanjutak, S. (2002) "Hasil kegiatan eksplorasi mineral logam kerjasama teknik asing, daerah Pegunungan Selatan Jawa Timur," in Kolokium Direktorat Inventarisasi Sumber Daya Mineral (DIM) TA. 2002. Bandung: Pusat Sumber Daya Geologi, pp. 1-8. Available at: http://psdg.bgl.esdm.go.id/kolokium 2002/08_Proseding logam1.pdf.

Wilkinson, J. . (2001) "Fluid inclusions in hydrothermal ore deposits," Lithos. Elsevier, 55(1-4), pp. 229-272. doi: 10.1016/S0024-4937(00)00047-5. 
